\title{
ANALISIS TINGKAT PENGETAHUAN WARGA TENTANG BHD
}

\author{
Shanti Dafris \\ Akper Kesdam I/Bukit Barisan Padang \\ Email: shantidafris0688@gmail.com
}

\begin{abstract}
ABSTRAK
Keterampilan Bantuan Hidup Dasar dapat diajarkan untuk siapapun. Semua lapisan masyarakat seharusnya diajarkan tentang Bantuan Hidup Dasar, baik orang dewasa sampai anak-anak, karena terkait pemberian pertolongan keselamatan. Tujuan penelitian ini yaitu untuk mengetahui tingkat pengetahuan warga Kelurahan Pasa Gadang Kecamatan Padang Selatan, tentang Bantuan Hidup Dasar. Penelitian ini penelitian kuantitatif. Dalam penelitian ini sampel diambil menggunakan purposive sampling yaitu warga Kelurahan Pasa Gadang Kecamatan Padang Selatan yang bertempat tinggal di area pinggir jalan raya sebanyak 30 responden. Hasil penelitian menunjukkan tingkat pengetahuan tentang BHD yang paling banyak adalah pengetahuan kurang sebanyak 18 orang (60\%), untuk sedang sebanyak 5 orang $(17 \%)$ dan untuk baik sebanyak 7 orang (23\%). Jadi dalam penelitian ini Tingkat pengetahuan warga tentang bantuan hidup dasar yang paling banyak adalah pengetahuann kurang sebanyak 18 orang $(60 \%)$
\end{abstract}

Kata Kunci : Bantuan Hidup Dasar, BHD, Pengetahuan

\begin{abstract}
ABSTRAK
Life Assistance Skills. All levels of society are issued about Basic Life Assistance, both adults and children, because this is related to the provision of safety assistance. The purpose of this study was to study the level of knowledge of residents of Pasa Gadang Village, Padang Selatan District, about Basic Life Assistance. This research is quantitative research. The sample of this research was purposive sampling, that is the residents of Pasa Gadang Village, Padang Selatan Subdistrict, who reside in the area of the highway by 30 respondents. The results showed the level of knowledge about basic life support (BHD) the most is less knowledge of 18 people (60\%), as many as 5 people (17\%) and for good as many as 7 people (23\%). So in this study the level of knowledge of citizens about basic life assistance the most is less than 18 people (60\%)
\end{abstract}

Kata Kunci : Basic Life Support, BHD, Knowledge 
PENDAHULUAN

Bantuan Hidup Dasar (BHD) adalah Pertolongan pertama yang dilakukan pada korban henti jantung atau henti napas sebelum ditangani oleh tenaga medis atau rumah saki.

Bantuan hidup dasar (BHD) ditujukan untuk mempertahankan potensi jalan nafas dan bantuan pernafasan dan sirkulasi, tanpa bantuan alat melainkan pelindung diri. waktu tanggap sejak Enhanced Message Service (EMS) diaktifkan hingga kedatangan sekitar 8 menit atau lebih. Dalam kurung waktu tersebut, kelangsungan hidup penderita sangat tergantung pada pertolongan pertama untuk mengaktifkan tiga untai dari rantai keselamatan (AHA, 2010).

Idealnya seseorang harus mampu melakukan BHD, karena pada akhirnya disebagian orang akan berada pada situasi yang perlu memerlukan pertolongan pertama baik untuk diri sendiri atau orang lain. Meskipun keterlambatan hanya beberapa menit saat jantung seseorang berhenti dapat memberikan perbedaan antara hidup dan mati, sebagian besar cidera tidak memerlukan usaha penyelamatan nyawa. Seumur hidupnya sebagian besar orang hanya akan melihat satu atau dua situasi yang melibatkan keadaan yang mengancam nyawa, menyelamatkan hidup penting, tetapi mengetahui apa yang harus dilakukan untuk cedera yang kurang berat dapat memerlukan perhatian yang lebih besar serta latihan pertolongan pertama yang lebih banyak (Thygerson, 2011).

Tidak seorangpun menghendaki hal yang buruk terjadi akan tetapi suatu yang tidak diharapkan seperti kecelakaan atau kedaruratan dapat saja terjadi secara tidak disangka-sangka. Apabila suatu kecelakaan terjadi disekitar maka harus dapat melakukan pertolongan pada korban atau diri sendiri. Namun harus dipastikan bahwa seorang penolong harus memiliki pengetahuan yang memadai untuk pertolongan itu dan harus betul-betul memahami tindakan yang akan dilakukan. Satu hal yang harus diperhatikan ketika terjadi kegawat daruratan pastikan bersikap tenang dan melakukan pertolongan dengan cepat dan tepat. 
Di Indonesia, jumlah kendaraan bermotor meningkat setiap tahunnya dan kelalaian manusia menjadi faktor utama terjadinya peningkatan kecelakaan lalu lintas. Data Kepolisian RI menyebutkan, pada 2012 terjadi 109.038 kasus kecelakaan dengan korban meninggal dunia sebanyak 27.441 orang, dengan potensi kerugian sosial ekonomi sekitar Rp 203 triliun - Rp 217 triliun per tahun $(2,9 \%-3,1 \%$ dari pendapatan domestik bruto/PDB Indonesia).

Berdasarkan data dari Satuan Kepolisian lalu lintas Resort Kota Padang pada Januari-November 2018, kasus kecelakaan tercatat sebanyak 614 kasus, sedangkan data Januari-Desember 2017 sebanyak 576 kasus. Tingginya angka kecelakaan lalu lintas tersebut menunjukkan bahwa banyak pengendara kendaraan bermotor yang belum memahami tentang pentingnya keselamatan berkendara (Arifin, 2014). Maka dari latar belakang tersebut peneliti tertarik untuk melakukan penelitian tentang pengetahuan warga kelurahan pasa gadang kecamatan padang selatan tentang bantuan hidup dasar (bhd).

\section{METODOLOGI}

Penelitian ini merupakan penelitian kuantitatif dengan desain deskriptif.
Populasi dalam penelitian ini adalah warga Kelurahan Pasa Gadang Kecamatan Padang Selatan. Dalam penelitian ini sampel yang digunakan yaitu menggunakan cara purposive sampling yaitu Warga Kelurahan Pasa Gadang Kecamatan Padang Selatan yang bertempat tinggal di area pinggir jalan raya dan memilih sebanyak 30 responden dengan kriteria, sebagai berikut :

1. Semua warga yang bertempat tinggal di pinggir jalan raya dari usia 17-55 tahun.

2. Bersedia menjadi responden.

3. Dapat berkomunikasi menggunakan bahasa Indonesia.

\section{HASIL}

\section{Karakteristik responden berdasarkan jenis kelamin}

Tabel 1.1

Karakteristik responden berdasarkan jenis kelamin

\begin{tabular}{|c|c|c|}
\hline $\begin{array}{c}\text { Jenis } \\
\text { kelamin }\end{array}$ & Frekuensi & Presentase \\
\hline Perempuan & 20 & 67 \\
\hline Laki -laki & 10 & 33 \\
\hline Total & $\mathbf{3 0}$ & $\mathbf{1 0 0}$ \\
\hline
\end{tabular}

Karakteristik respondenpada penelitian ini berdasarkan jenis kelamin yang paling banyak adalah jenis kelamin Perempuan sebanyak 20 orang $(67 \%)$. 
2. Tingkat pengetahuan tentang bantuan hidup dasar

Tabel 1.2

Tingkat pengetahuan tentang bantuan hidup dasar

Tingkat Frekuensi Persentase

\begin{tabular}{lcc} 
Pengetahuan & & $(\%)$ \\
\hline Baik & 7 & 23 \\
Sedang & 5 & 17 \\
Kurang & 18 & 60 \\
\hline Total & 30 & 100 \\
\hline
\end{tabular}

Tingkat pengetahuan tentang bantuan hidup dasar yang paling banyak adalah rendah sebanyak 18 orang (60\%), sedang sebanyak 5 orang $(17 \%)$ dan baik sebanyak 7 orang (23\%).

\section{PEMBAHASAN}

Dari hasil penelitian dapat diartikan mayoritas responden yaitu perempuan. Hasil penelitian ini sama dengan hasil penelitian Dahlan, Kumaat, \& Onibala (2014) karena mayoritas responden dalam penelitian ini juga berjenis kelamin perempuan sebanyak 43 orang (86\%). Hal ini disebabkan jumlah tenaga kesehatan Puskesmas Wori mayoritas berjenis kelamin perempuan.

Hasil penelitian tersebut sejalan dengan hasil penilitian Dahlan, Kuumat \& Onibala (2014) yang menunjukka nilai rata-rata sebelum diberikan penyuluhan pendidikan bagi tenaga kesehatan di Puskesmas Wori tentang BHD adalah sebesar 32,90 sedangkan setelah diberikan penyuluhan pendidikan kesehatan diperoleh nilai rata-rata 82,40 yang berarti terjadi peningkatan nilai rata-rata sebesar 49,50.

Pengetahuan tentang Bantuan Hidup Dasar (BHD) sangat diperlukan oleh seluruh kalangan masyarakat dan bahkan sejak tingkat usia sekolah. Tenaga kesehatan yang merupakan ujung tombak untuk peningkatan derajat kesehatan seharusnya lebih meningkatkan pengetahuan untuk menunjang perilaku dalam melakukan pelayanan kesehatan. Salah satu faktor yang mempengaruhi perilaku seseorang yaitu tingkat pengetahuan. Pengetahuan tentang BHD akan mempengaruhi perilaku akan pemberian pertolongan pertama pada korban yang perlu diberikan BHD. Salah satu upaya untuk meningkatkan pengetahuan adalah dengan pendidikan kesehatan.

Hasil penelitian ini tidak sesuai dengan teori Notoatmodjo (2003) dalam Hutapea, Elda Lunera (2012) menyatakan bahwa orang- orang yang memiliki pendidikan yang lebih tinggi akan memiliki pengetahuan yang lebih tinggi pula jika dibandingkan dengan orangorang yang memiliki pendidikan yang rendah. Perbedaan tersebut disebabkan belum adanya pendidikan tentang 
bantuan hidup dasar yang di dapat dari berbagai jenjang pendidikan yang ada di Indonesia.

\section{KESIMPULAN}

1. Karakteristik responden pada penelitian ini didapatkan hasil bahwa jenis kelamin yang paling banyak adalah jenis kelamin Perempuan sebanyak 20 orang.

2. Tingkat pengetahuan tentang bantuan hidup dasar yang paling banyak adalah kurang sebanyak 18 orang, sedang sebanyak 5 orang dan baik sebanyak 7 orang.

\section{DAFTAR PUSTAKA}

Arifin, M.Zaenal.2014.Kecelakaan lalu lintas di Jateng.Tribun Jateng.

Arikunto, Suharsimi.(2013).Prosedur Penelitian: Suatu Pendekatan Praktik Jakarta:Rineka Cipta

Erawati, Susi.(2015). Tingkat pengetahuan masyarakat tentang bantguan hidup dasar (BHD) di kota administrasi jakarta selatan.skripsi.Fakultas Kedokteran dan Ilmu Kesehatan.Jakarta. Universitas Islam Negeri Syarif Hidayatullah

Notoatmodjo, S.(2010). Promosi Kesehatan: Teori dan Aplikasi (Edisi Revisi 2011 